\title{
Morbidity of Chagas heart disease in the microregion of Rio Negro, Amazonian Brazil: a case-control study
}

\author{
José Rodrigues Coura ${ }^{1} /{ }^{+}$, Pedro Albajar Viñas², Lucia Maria Brum-Soares ${ }^{3}$, \\ Andréa Silvestre de Sousa ${ }^{4}$, Sérgio Salles Xavier ${ }^{4}$ \\ ${ }^{1}$ Laboratório de Doenças Parasitárias, Instituto Oswaldo Cruz ${ }^{4}$ Instituto de Pesquisa Clínica-Fiocruz, \\ Rio de Janeiro, RJ, Brasil ${ }^{2}$ Department of Neglected Tropical Disease, \\ World Health Organization, Geneva, Switzerland ${ }^{3}$ Médicos sem Fronteiras, Brasil
}

\begin{abstract}
A case-control study on the morbidity of Chagas heart disease was carried out in the municipality of Barcelos in the microregion of the Rio Negro, state of Amazonas. One hundred and six individuals, who were serologically positive for Trypanosoma cruzi infection, as confirmed by at least two techniques with different principles, were matched according to age and sex with an equal number of seronegative individuals. The cases and controls were evaluated using an epidemiological questionnaire and clinical, electrocardiograph and echocardiograph examinations. In the seroepidemiological evaluation, $62 \%$ of the interviewees recognised triatomines and most of them confirmed that they had seen these insects in the piassava plantations of the riverside communities of the Negro River tributaries. Of the seropositive patients, $25.8 \%$ affirmed that they had been stung by the triatomines and $11.7 \%$ denied having been stung. The principal clinical manifestations of the seropositive individuals were palpitations, chest pain and dyspnoea upon effort. Cardiac auscultation revealed extrasystoles, bradycardia and systolic murmurs. The electrocardiographic alterations were ventricular extrasystoles, left and right bundle branch block, atrioventricular block and primary $T$ wave alterations. The echocardiogram was altered in $22.6 \%$ of the seropositive individuals and in $8.5 \%$ of the seronegative individuals.
\end{abstract}

Key words: Chagas heart disease - morbidity - case control study - Amazon Region

In the Brazilian Amazon, Chagas disease has always been considered an enzootic disease of wild animals since Carlos Chagas (1924) first confirmed that the parasites found in Saimiri sciureus monkeys were Trypanosoma cruzi. Since then, 38 species of wild mammals belonging to the Marsupialia (Didelphiomorphia), Chiroptera, Rodentia, Edentada (Xenarthra), Carnivora and Primate orders have been described in this region by several authors, as cited by Coura and Junqueira (2012).

Shaw et al. (1969) described the first four acute human cases of Chagas disease in the municipality of Belém, state of Pará (PA) and numerous cases of the disease have been described in the states of Amapá, Amazonas (AM), Maranhão, Acre and PA (Coura et al. 1993, 1994, 1999, 2002, Valente \& Valente 1993, Valente et al. 1994, 1999, 2009, Pinto et al. 2001, 2003, 2004, 2008, 2013, Dias et al. 2002, Magalhães et al. 2011, BrumSoares et al. 2010, Coura \& Junqueira 2012, Junqueira et al. 2013, Souza-Lima et al. 2013).

In three seroepidemiological surveys that we carried out in the study area in 1991, 1993 and 1997, which involved 2,254 inhabitants of the area, we found that the serological prevalence of $T$. cruzi infection in screening

doi: $10.1590 / 0074-0276130425$

+ Corresponding author: coura@ioc.fiocruz.br

Received 2 September 2013

Accepted 29 November 2013 tests were $12.5 \%, 13.7 \%$ and $13.2 \%$, respectively (Coura et al. 1995a, b, 1999, 2002). However, the immunofluorescence (IIF), ELISA and Western blot (TESA-blot) tests performed on the serum only confirmed $2.8-5 \%$ of the seropositive individuals as positive. More recently (2010/2011), a screening seroepidemiological study using IIF on blood collected in filter paper was performed with 4,480 residents in the study area. In this study, 221 were strongly reactive and were considered positive, while 302 were weakly reactive and were considered doubtful (Coura et al. 2013). Ferraroni et al. (1977) were the first to serologically confirm chronic cases of Chagas infection among autochthonous patients in the municipality of Barcelos in the microregion of the Negro River, AM. Souza-Lima et al. (1985) described the first acute case of Chagas disease, which resulted from a mixed infection with $T$. cruzi and Trypanosoma rangeli in that municipality. Several cases of Chagas disease were described by our group in the same area, including two fatal cases (Coura et al. 1995b, Albajar et al. 2003, Xavier et al. 2006, Brum-Soares et al. 2010, Junqueira et al. 2013). A previous paired study on the morbidity of Chagas disease in the same area was carried out by Brum-Soares et al. (2010) and included cardiac evaluations of 38 seropositive and seronegative pairs and 29 pairs evaluated by means of radiography of the oesophagus. Recently, an outbreak of 17 acute cases of Chagas disease was described in Santa Izabel do Rio Negro; this outbreak was caused by oral transmission (Souza-Lima et al. 2013) and added to the other cases that have occurred in the region of the Solimões River. 
Four epidemiological profiles for Chagas disease can be observed in the Amazon Region: (i) enzootic disease of wild animals throughout the region, (ii) anthropozoonosis, i.e., accidental human infection by $T$. cruzi when man invades the wild ecotope or when triatomines and wild reservoirs of $T$. cruzi (marsupials) invade human homes, (iii) acute disease caused by oral transmission of T. cruzi through ingestion of food contaminated with the faeces and/or urine of wild triatomines or with the odoriferous secretions of marsupials, thus causing epidemic outbreaks of acute Chagas disease and (iv) professional disease from plant extraction workers, especially those who work with piassava fibre. The main aim of the present study was to evaluate the morbidity of Chagas heart disease using case-control study in the area, where most cases occur among piassava extractors.

\section{PATIENTS, MATERIALS AND METHODS}

The municipality of Barcelos is the largest in AM and the second largest in Brazil with an area of 122,476 $\mathrm{km}^{2}$. It is located in the northern part of the state in the Negro River microregion. It is bordered to the east by the state of Roraima, to the south and southeast by the municipalities of Novo Airão and Marãa, to the west by the municipality of Santa Izabel do Rio Negro and to the north by Venezuela $\left(0^{\circ} 58^{\prime} 56^{\prime}\right.$ 'S latitude and $62^{\circ} 56^{\prime} \mathrm{W}$ longitude). The main settlement in the municipality is located on the west bank of the Negro River, $490 \mathrm{~km}$ upriver from Manaus, the capital of the state (Fig. 1).

A case-control study was conducted to assess the morbidity of Chagas heart disease in 106 patients who were serologically positive for $T$. cruzi infection with confirmation from at least two techniques with different principles (IIF, conventional ELISA, recombinant ELISA and/or TESA-blot). This sample included patients from all the studies conducted in the area over the past 20 years who presented confirmed serological reactions and for whom clinical, electrocardiographic and echocardiographic examinations were available. These patients were paired with seronegative individuals of the same age, sex and social conditions. The patients and their respective controls were interviewed and, after giving their

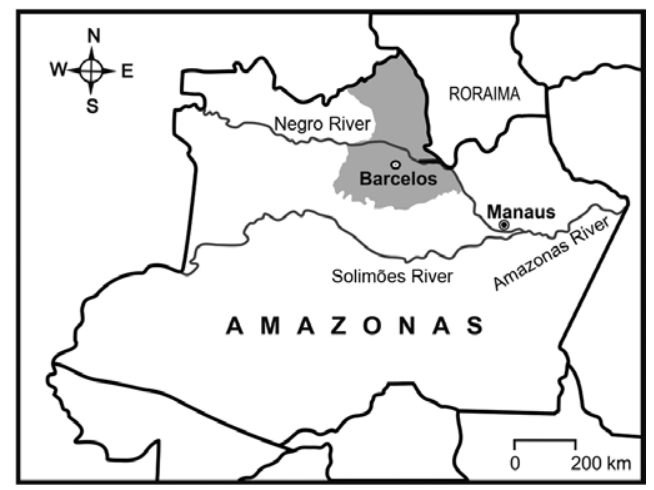

Fig. 1: location of the municipality of Barcelos in the microregion of the Negro River, state of Amazonas. informed consent, they were evaluated regarding their exposure to infection, particularly their contact with and stings from triatomines, working conditions and symptoms. They also underwent clinical, electrocardiographic and echocardiographic examinations. The subjects with hypertension and/or with other heart disease not related with Chagas disease were excluded from the study. The clinical examination included multiple organs and systems, especially the cardiac region, with auscultation of at least $1 \mathrm{~min}$. The electrocardiogram (ECG) was produced using the 12 classic derivations with at least three complexes and one long D2. A portable echocardiograph (ESAOTE, SIM 5000 model) was used to generate the standard echocardiographic planes - parasternal and apical - that are important for identifying small apical aneurysms. Functional measurements of the left ventricle (LV) were obtained in accordance with the recommendations of the American Society of Echocardiography. The ejection fraction was estimated using the M mode and the systolic functional evaluation of the LV was performed using two-dimensional echocardiography in a subjective manner. The contractile function of the right ventricle was assessed via the tricuspid ring of the systolic excursion. All of the echocardiographic evaluations were carried out as described by Xavier et al. (2006).

\section{RESULTS}

In the questionnaire, $62 \%$ of the interviewees recognised triatomines when shown samples of the genera Rhodnius, Panstrongylus and Triatoma. Among the seropositive individuals, $25.8 \%$ affirmed that they had been stung by these insects, while only $11.7 \%$ denied having been stung by triatomines. This difference was considered to be statistically significant $(p=0.03)$.

In the questionnaire and in the clinical examination, $28.3 \%$ of the seropositive individuals reported palpitations, $24.4 \%$ reported chest pain and $22.6 \%$ reported dyspnoea on effort. Among the seronegative individuals, only $8.5 \%, 6.6 \%$ and $4.7 \%$ reported these symptoms, respectively, with a gradient of $19.8 \%, 17.8 \%$ and $17.9 \%$, respectively. In the clinical examination of the seropositive individuals, $13.2 \%$ presented heart arrhythmia on auscultation, $11.3 \%$ presented bradycardia and 7.5\% presented systolic murmur, while only $2.8 \%, 8.5 \%$ and $1.9 \%$ of the seronegative individuals, respectively, presented these signs (Table I).

The ECGs showed that $11.3 \%$ of the seropositive individuals presented ventricular extrasystoles, $7.5 \%$ presented bradycardia, $7.5 \%$ presented left bundle branch block (LBBB) of the bundle of His, 3.8\% presented right bundle branch block (RBBB), $1.9 \%$ presented atrioventricular (AV) block and 3.8\% presented ventricular repolarisation alterations (flat $\mathrm{T}$ wave). Among the seronegative subjects, $0.9 \%$ presented ventricular extrasystoles, $5.6 \%$ presented bradycardia, $1.9 \%$ had first-degree RBBB and $1.9 \%$ had first-degree AV block (Table II). The frequency of LBBB was noteworthy because it is typically rare in Chagas disease in the endemic areas. Fig. 2 shows a typical case of Chagas disease with an increase in the heart area seen on the chest radiograph, polymorphic extrasystoles on the ECG and a third-degree 
RBBB with left anterior hemiblock (fascicular block). The echocardiogram (ECHO) was altered in $22.6 \%$ of the seropositive individuals and in $8.5 \%$ of the seronegative individuals, a difference of $14.1 \%$ (Table III). Fig. 3 shows a typical ECHO for Chagas disease observed in the study area, characterised by septal hypokinesis, posterior wall akinesis and a finger-like left apical aneurysm (Xavier et al. 2006).

From the above observations, we can conclude that Chagas disease in the study area is of low morbidity and is directly related to the intensity of exposure, particularly among the piassava fibre gatherers (Albajar 2003, Brum-Soares et al. 2010). As found by Brum-Soares et al. (2010), the radiography of the oesophagus did not present alterations in 29 seropositive patients studied in the area.

\section{DISCUSSION}

Serologically diagnosing T. cruzi infection in the study area is extremely complex because of the large number of cross-reactions with other infections that occur in this area, including malaria, leishmaniasis, tuberculosis, leprosy and T. rangeli infection. Thus, the patterns of serological diagnoses differ from those used in the classical endemic regions for Chagas disease in Bra-

\section{TABLE I}

Clinical manifestation of

Chagas heart morbidity in the Amazon Region

\begin{tabular}{lccc}
\hline $\begin{array}{l}\text { Clinical } \\
\text { manifestations }\end{array}$ & $\begin{array}{c}\text { Seropositives } \\
\mathrm{n}(\%)\end{array}$ & $\begin{array}{c}\text { Seronegatives } \\
\mathrm{n}(\%)\end{array}$ & $\begin{array}{c}\text { Gradient } \\
(\%)\end{array}$ \\
\hline Palpitations & $30(28.3)$ & $9(8.5)$ & 19.8 \\
Heart pain & $28(24.4)$ & $7(6.6)$ & 17.8 \\
Effort dyspnoea & $24(22.6)$ & $5(4.7)$ & 17.9 \\
Syncope & $2(1.9)$ & $0(0)$ & 1.9 \\
Cardiac arrhythmia & $14(13.2)$ & $3(2.8)$ & 10.4 \\
Bradycardia & $12(11.3)$ & $9(8.5)$ & 2.8 \\
Systolic murmur & $8(7.5)$ & $2(1.9)$ & 5.6 \\
\hline
\end{tabular}

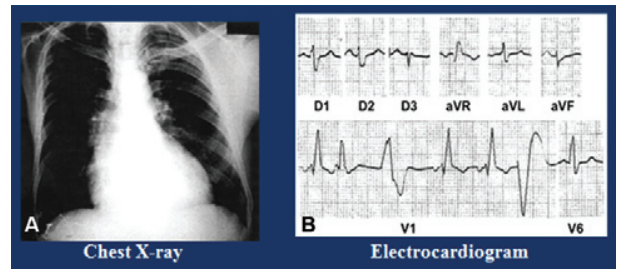

Fig. 2: Chagas heart diseases autochthonous of the municipality of Barcelos in the microregion of the Negro River, state of Amazonas. A: chest X ray, enlargement of the heart; B: electrocardiogram, right bundle branch block third degree with left anterior hemiblock (fascicular block) and polymorphic ventricular extrasystoles.

TABLE III

Echocardiogram (ECHO)

of Chagas heart morbidity in the Amazon Region

\begin{tabular}{lccc}
\hline ECHO & $\begin{array}{c}\text { Seropositives } \\
\mathrm{n}(\%)\end{array}$ & $\begin{array}{c}\text { Seronegatives } \\
\mathrm{n}(\%)\end{array}$ & $\begin{array}{c}\text { Gradient } \\
(\%)\end{array}$ \\
\hline Abnormal $^{a}$ & $24(22.6)$ & $9(8.5)$ & 14.1 \\
Normal & $82(77.4)$ & $97(91.5)$ & -
\end{tabular}

$a$ : low ejection fraction, myocardial segmental impairment, apical ventricle aneurysm, posteroinferior or septal akinesis or hypokinesis.

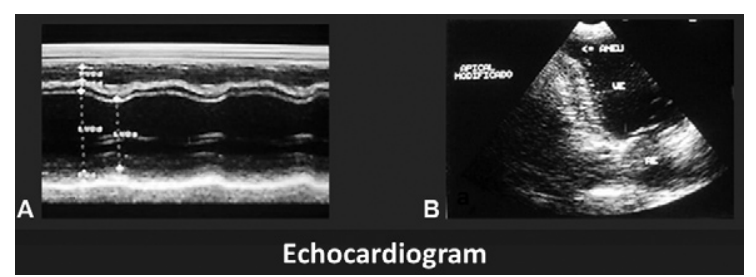

Fig. 3: echocardiogram showing akinesis of posterior wall (A) and left ventricular apical aneurysm (B).

TABLE II

Electrocardiogram (ECG) of Chagas heart disease morbidity in the Amazon Region

\begin{tabular}{lccc}
\hline ECG abnormalities & $\begin{array}{c}\text { Seropositives } \\
\mathrm{n}(\%)\end{array}$ & $\begin{array}{c}\text { Seronegatives } \\
\mathrm{n}(\%)\end{array}$ & $\begin{array}{c}\text { Gradient } \\
(\%)\end{array}$ \\
\hline Ventricular extrasystoles & $12(11.3)$ & $1(0.9)$ & 10.4 \\
Bradycardia & $8(7.5)$ & $6(5.6)$ & 1.9 \\
LBBB (grade 3) & $8(7.5)$ & $0(0)$ & 7.5 \\
RBBB (grade 3) & $2(1.9)$ & $0(0)$ & 1.9 \\
RBBB (grade 1) & $2(1.9)$ & $2(1.9)$ & 0 \\
AV B (grade 1) & $2(1.9)$ & $0(0)$ & 0 \\
Flat T wave & $4(3.8)$ & 3.9 & \\
\hline
\end{tabular}

AV B: atrioventricular block; LBBB: left bundle branch block; RBBB: right bundle branch block. 
zil. Therefore, the recommendation is that serological evaluations of T. cruzi infection in the Amazon Region should be confirmed by at least two techniques with different principles, such as IIF on the serum, ELISAs and, when possible, Western blots (Coura et al. 2013).

The determining factors for morbidity due to Chagas disease in the study area are directly related to the population's exposure to wild vectors, particularly in the piassava plantations in the region, and are also likely associated with the different $T$. cruzi strains circulating in the area, TcI and Z3 (wild), which still present little adaptation to human and experimental infections. Araujo (2000) conducted analyses in our laboratory at the Oswaldo Cruz Institute, Oswaldo Cruz Foundation, on 10 T. cruzi strains that were isolated in our study area of piassava crops in the riverside communities of tributaries of the Negro River. Of these strains, two were isolated from human beings, two from marsupials and six from Rhodnius brethesi. These analyses revealed the following: (i) all of the evaluated samples presented a predominance of broad forms, (ii) the majority of the study samples inoculated in mice showed low parasitaemia and virulence, (iii) histopathological evaluations showed that amastigote nests and inflammatory infiltrate were present, especially in the heart and skeletal muscles, (iv) the biological behaviour of the T. cruzi samples showed great heterogeneity regarding infectivity, parasitaemia and virulence and (v) the T. cruzi samples showed great phenetic heterogeneity, with no correspondence between the isoenzyme profiles and biological behaviour.

The excessive presence of LBBB observed in the present study was twice as common as the RBBB of the bundle of His and differed from the typical electrocardiographic patterns of Chagas disease in which the occurrence rate of LBBB is usually approximately $2 \%$. This could simply be a coincidence in the small sample studied here or could represent a new pattern for Chagas disease in this region. However, there were no findings of megaoesophagus in the paired study carried out by Brum-Soares et al. (2010) and likewise we did not find any cases of megaoesophagus in the sporadic cases in which radiography was performed on the oesophagus, even though such findings are characteristic of the Chagas disease profile in areas north of the equator.

\section{REFERENCES}

Albajar PV 2003. Emergência da infecção chagásica humana em áreas do Rio Negro, estado do Amazonas, $\mathrm{PhD}$ Thesis, Instituto Oswaldo Cruz-Fiocruz, Rio de Janeiro, 114 pp.

Albajar PV, Laredo SV, Terrazas MB, Coura JR 2003. Miocardiopatia dilatada em pacientes com infecção chagásica crônica. Relato de dois casos fatais autóctones do Rio Negro, estado do Amazonas. Rev Soc Bras Med Trop 36: 401-407.

Araujo IB 2000. Estudo morfobiológico, histopatológico e isoenzimático de isolados de Trypanosoma cruzi (Chagas 1909) e Trypanosoma rangeli (Tejera 1920), MsD Thesis, Instituto Oswaldo Cruz-Fiocruz, Rio de Janeiro, 125 pp.

Brum-Soares LM, Xavier SS, Sousa AS, Pereira JB, Ferreira JMBB, Costa IR, Junqueira ACV, Coura JR 2010. Morbidade da doença de Chagas em pacientes autóctones da microrregião do Rio Negro, estado do Amazonas. Rev Soc Bras Med Trop 43: 170-177.
Chagas C 1924. Infection naturelle dês singes du Pará (Chrysotrix sciureus) par Trypanosoma cruzi. Comp Rend Séanc Soc Biol Ses Fin 90: 873-876.

Coura JR, Junqueira ACV 2012. Risks of endemicity, morbidity and perspectives regarding the control of Chagas disease in the Amazon Region. Mem Inst Oswaldo Cruz 107: 145-154.

Coura JR, Junqueira ACV, Boia MN, Fernandes O 1999. Chagas disease: from bush to huts and houses. Is it the case of the Brazilian Amazon? Mem Inst Oswaldo Cruz 94 (Suppl. I): 379-384.

Coura JR, Junqueira ACV, Fernandes O, Valente SAS, Miles MA 2002. Emerging Chagas disease in Amazonian Brazil. Trends Parasitol 18: 171-176.

Coura JR, Junqueira ACV, Giordano CM, Funatsu RK 1994. Chagas disease in the Brazilian Amazon. I - A short review. Rev Inst Med Trop São Paulo 36: 363-368.

Coura JR, Marquez MHP, Guerra JAO, Zauza PL, Miguel JC, Pereira JB 2013. A new survey of the serology of human Trypanosoma cruzi infection in the Rio Negro microregion, Brazilian Amazon: a critical analysis. Mem Inst Oswaldo Cruz 108: 909-913.

Coura JR, Naranjo MA, Willcox HPF 1993. Doença de Chagas na Amazônia brasileira. Rev Soc Bras Med Trop 26 (Suppl. 2): 15-17.

Coura JR, Naranjo MA, Willcox HPF 1995a. Chagas disease in the Brazilian Amazon. II - A serological survey. Rev Inst Med Trop Sao Paulo 37: 103-107.

Coura JR, Willcox HPF, Naranjo MA, Fernandes O, Paiva DD 1995b. Chagas disease in the Brazilian Amazon. III - A cross-sectional study. Rev Inst Med Trop Sao Paulo 37: 415-420.

Dias JCP, Prata A, Schofield CJ 2002. Doença de Chagas na Amazônia: esboço da situação atual e perspectiva de prevenção. Rev Soc Bras Med Trop 35: 669-678.

Ferraroni JJ, Mello JAN, Camargo ME 1977. Moléstia de Chagas na Amazônia. Ocorrência de seis casos suspeitos, autóctones, sorologicamente positivos. Acta Amaz 7: 438-440.

Junqueira ACV, Albajar PV, Coura JR 2013. Doença de Chagas na Amazônia brasileira. In JR Coura, Dinâmica das doenças infecciosas e parasitárias, 2nd ed., Grupo GEN/Guanabara Koogan, Rio de Janeiro, p. 642-646.

Magalhães BML, Coelho LIARC, Maciel MG, Umezawa ES, Coura JR, Guerra JAO, Barbosa MGV 2011. Serological survey for Chagas disease in rural areas of Manaus, Coarí and Tefé, in the Western Brazilian Amazon. Rev Soc Bras Med Trop 44: 697-702.

Pinto AYN, Harada GS, Valente VC, Abud JE, Gomes FD, Souza GC, Valente SAS 2001. Cardiac attacks in patients with acute Chagas disease in a family micro-outbreak, in Abaetetuba, Brazilian Amazon. Rev Soc Bras Med Trop 34: 413-419.

Pinto AYN, Valente SAS, Lopes R, Silva O, Castro T, Valente VC 2003. Ocorrência de tripanosomíase aguda familiar no município de Igarapé-Miri, Pará: gravidade de apresentação clínica em idosos. Rev Soc Bras Med Trop 36 (Suppl. 1): 381.

Pinto AYN, Valente SAS, Valente VC 2004. Emerging acute Chagas disease in Amazonian Brazil: case reports with serious cardiac involvement. Braz J Infect Dis 8: 454-460.

Pinto AYN, Valente SAS, Valente VC, Ferreira-Junior AG, Coura JR 2008. Fase aguda da doença de Chagas na Amazônia brasileira. Estudo de 233 casos do Pará, Amapá e Maranhão observados entre 1988 e 2005. Rev Soc Bras Med Trop 41: 602-614.

Pinto AYN, Valente VC, Coura JR, Valente SAS, Junqueira ACV, Santos LC, Ferreira Jr AG, Macedo RC 2013. Clinical follow-up of response to treatment with benznidazol in Amazon: a cohort study of acute Chagas disease. PLOS ONE 8: e64450. 
Shaw J, Lainson R, Fraiha H 1969. Considerações sobre a epidemiologia dos primeiros casos autóctones de doença de Chagas registrados em Belém, Pará, Brasil. Rev Saude Publica 3: 153-157.

Souza-Lima MZ, Santos IKF, Souza AA, Naiff RD, Czeco YMT, Miles MA 1985. Caso humano de infecção mista por Trypanosoma cruzi e organismos tipo Trypanosoma rangeli procedente de Barcelos, Rio Negro, Amazonas. In Proceedings of the XXI Congresso da Sociedade Brasileira de Medicina Tropical, São Paulo, p. 44.

Souza-Lima RC, Vale MG, Coura JR, Arcanjo ARL, Nascimento AS, Ferreira JMBB, Magalhães LK, Albuquerque BC, Araujo GAN, Guerra JAO 2013. Outbreak of acute Chagas disease associated with oral transmission in the Rio Negro region, Brazilian Amazon. Rev Soc Bras Med Trop 46: 515-518.

Valente SAS, Valente CV, Pinto AYN, César MJR, dos Santos MP, Miranda COS, Cuervo P, Fernandes O 2009. Analysis of an acute
Chagas disease outbreak in the Brazilian Amazon: human cases, triatomines, reservoir mammals and parasites. Trans $R$ Soc Trop Med Hyg 103: 291-297.

Valente SAS, Valente VC 1993. Situação atual da doença de Chagas na Amazônia. Rev Soc Bras Med Trop 26 (Suppl. 2): 68-70.

Valente SAS, Valente VC, Ferreira SM, Santos TCM, Moura E, Uchoa AD 1994. Registro de doença de Chagas aguda em Sena Madureira, estado do Acre. Rev Soc Bras Med Trop 27 (Suppl. 1): 169.

Valente SAS, Valente VC, Fraiha Neto H 1999. Considerations on the epidemiology and transmission of Chagas disease in the Brazilian Amazon. Mem Inst Oswaldo Cruz 94 (Suppl. I): 395-398.

Xavier SS, Souza AS, Albajar PV, Junqueira ACV, Boia MN, Coura JR 2006. Cardiopatia chagásica crônica no Rio Negro, estado do Amazonas. Relato de três novos casos autóctones comprovados por exames sorológicos, clínicos, radiográficos do tórax, eletro e ecocardiográficos. Rev Soc Bras Med Trop 39: 211-216. 